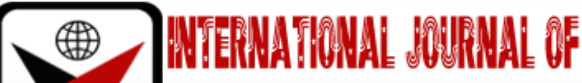

\section{Public Infrastructure A Panacea towards Poverty Reduction in Anyamelum Local Government of Anambra State, Nigeria}

\author{
Dr. Chukwurah D.C.J. \\ Professor, Department of Public Administration, \\ OdimegwuOjukwu, University Igbariam, Anambra State, Nigeria \\ EzenwegbuNchedochukwuChinwendu \\ Academic Researcher, Department of Public Administration, \\ NnamdiAzikiwe University, Awka, Anambra State, Nigeria \\ Dr. Anazodo Rosemary \\ Senior Lecturer, Department of Public Administration \\ NnamdiAzikiwe University, Awka, Anambra State, Nigeria
}

\begin{abstract}
In spite of government initiatives available evidence shows that infrastructural facilities location in Anambra state is very lopsided mainly in rural areas. The study adopted descriptive survey design in examining the relationship between public infrastructure and poverty reduction in Anyamelum local government areas. The tools used for data collection from primary sources were questionnaires, interviews and personal observation and Questionnaire was analyzed using Statistical package for social science. The researchers made use of Taro Yemani's formula of 1964, for determining sample size from which is 204. A modified five (5) point's Likert scale designed was used in collecting the data from the respondents.The study revealed that, the level of poverty in Anyamelum local government rural area tend to be high because of the poor and inadequate public infrastructures in the area, such as roads, pipe borne water, well equipped hospital, market facilities and well equipped basic education, skill acquisition centers and so on; The study also revealed that, the poor and inadequate power supply plus the poor road condition in the study area have discourage the growth and development of small and medium scale business or enterprise (SME) in the area.The study therefore made the following recommendations; To eliminate poverty rate mainly in the rural areas compared to urbans, there is need for government to focus the provision or building of public infrastructures. Finally, Anambra state Government should set up or establish a Modern Agency that will undertake the provision and maintenance of infrastructural facilities in rural areas. This agency will eloquent all the rural growth plans which will amuse the entire needs of the rural people.
\end{abstract}

Keywords: Public infrastructure, poverty reduction

\section{Introduction}

China's impressive economic development with per capita income quadrupling and poverty falling significantly since the 1980s is the result of many factors, including promotion of private initiative, investment in infrastructure and opening to the outside world. Development has had the biggest impact on the country's coastal provinces. In reducing poverty in the hinterlands, China embarked on a 'go west' strategy, part of which involves construction of a 625 kilometre railway from Chongqing to Huaihua, thereby increasing access to the Red Basin and its 120 million inhabitants.

Supported by German Financial Cooperation, the new railway was a good example of a transport project that aims to reduce poverty by increasing transport efficiency and economic growth. The railway reduces the average distance travelled along the corridor by 275 kilometres, to 370 kilometres, saving money and time. The resulting growth effects through increased trade, productivity and division of labour - benefited the poor. Apart from impacts on the national economy, regional poverty impacts can be expected from the transport opportunities created in very poor areas. Residents of these areas should benefit from increased trade, market integration, urbanization, mining, agricultural production and processing, tourism and new businesses.

The project design is pro-poor in several respects. Attention was paid to connecting a large number of poor townships and small cities to the railway, creating opportunities for manufacturing and services as an alternative to farming in mountainous areas. Moreover, infrastructure developed during railway construction (roads, bridges, buildings, drinking water stations, electricity lines) was designed for permanent use. Employment was generated for the local poor through labour contracts and procurement of local construction material. And by cutting transport distances and diverting road traffic to the more environment-friendly railway, the project has saved energy and reduced pollution.(OECD, 2007). Poverty reduction requires economic growth which, when accompanied by sound macroeconomic management and good governance, results in sustainable and socially inclusive development (ADB 1999, Ali \& Pernia, 2003). Greater access of the 
poor to education and health services, water and sanitation, employment, credit, and markets for produce is needed. Moreover, the vulnerability of the poor to economic shocks and natural disasters must be reduced to enhance their wellbeing and encourage investment in human capital and in higher-risk and higher-return activities. Public policy reforms and investment in physical infrastructure will significantly contribute to the pursuit of socially inclusive development (Ali \& Pernia, 2003). Many infrastructural developments have been carried out by the Anambra state government as more than $75 \%$ of Anambraians live in the rural areas (Shehu, Ezenwegbu\&Suileman, 2015). Lack of opportunities has increased the problem of poverty inhabitants (Shehu and Ezenwegbu\&Suliman, 2015).

\section{Conceptual and Theoretical Framework}

Transportation, communications and water supply are called infrastructural facilities as without these primary, secondary and tertiary productive activities cannot function (Mabogunje, 1976, Ojeifo, 2012, Shehu et al, 2015).Physical (conveyance, storing, dispensation, water), social (fitness, teaching, efficacies) and institutional (supportive societies, financial organizations, agricultural research and training and product marketing) infrastructures are broadly the main three types of rural facilities in Anambra (Idachaba, 1985,0jeifo, 2012,Shehu et al, 2015). Rural infrastructure are those facilities and services aim to improve quality of life.

\section{Concept of Poverty}

Poverty is adeplorabledeficiency in well-being. Lack of the means to fulfil critical needs gives birth to it.Aluko (2000) highlighted some reasons behind the poverty including: not having sufficient food, alarming rate of newborn death, a low life expectation, low educational chances, and lack of active contribution in decision making.Bradshaw (2006) enumerated five theories of poverty. The first is the economic theory that the poor lacks inducements for improving their conditions and blame the welfare system. The second theory ancestries the reason of poverty in the 'culture of poverty'. The third theory is the liberal social theory which depends on the financial, partisan and communal systems. The forth theory states that geographical disparities are the main logic behind poverty. The fifth theory of poverty highlighted that spiral of opportunity and problems caused poverty at the individuals and in their community. Here, inadequate infrastructures mainly have caused poverty.

\section{Indicators of Poverty}

Economic performance as well as the standard of living of the population is usually the general factors used as indicators of poverty. These factors combine measures of purchasing power or income or consumption with other social indices which show availability and access to education, healthcare delivery, basic infrastructure and other welfare facilities in order to define the incidence, intensity or severity and the distribution of poverty within a population (Shehu and Ezenwegbu\&Suliman 2015).

CBN (1999) said that indicators of poverty from a general perceptive 'focus on measures of economic performance as well as the standard of living of the population.' It defends such a method as being appropriate in the sense that it 'combines measures of income or purchasing power or consumption with those social indicators which highlight availability and access to healthcare delivery, education, basic infrastructure and other welfare-enhancing facilities in order to define the incidence of poverty (how many are poor), the intensity or severity of poverty (how poor are they) and the distribution of poverty within a population'.

\section{Causes of Poverty}

There seems to be narrow disagreement on the causes of poverty as against the difficulty encountered in arriving a universally accepted definition of poverty. Although writers tend to discuss of poverty mostly from their areas of profession, region or gender, there are basic factors that enable the prevalence of poverty. These basic factors, including aero-economic distortions, effects of globalization, governance, corruption, debt burden, low productivity, unemployment, high population growth rate and poor human resources development and so on, may differ from country to country depending on the level of economic development. There are however, many issues involved when looking at the causes of poverty. Some are fundamental while others are not (Shehu and Ezenwegbu\&Suliman 2015).

While the CBN (1999:12) grouped causes of poverty into two categories 'namely low economic growth and market imperfections', the World Bank (2003:34) reasoned that 'one route of investigating the causes of poverty is to examine the dimensions highlighted by poor people':

- Lack of income and assets to attain basic necessities - food, shelter, clothing, and acceptable levels of health and education;

- Sense of voicelessness and powerlessness in the institutions of state and society; and

- Vulnerability to adverse shocks, linked to an inability to cope with them.' On the other hand, Federal Office of Statistics (1996:109) was definite in categorizing the causes of poverty in Anambra is into problems of access and endowments such as:

- Inadequate access to employment opportunities for the poor. This is often caused by the stunted growth of economic activities or growth with labour saving device;

- Lack or inadequate access to assets such as land capital by the poor: this is often attributed to the absence of land reform and minimal opportunities for small-credit; 
- Inadequate access to the means of fostering rural development in poor regions: the preference for high potential areas and the strong urban bias in the design of development programmes is often assumed to be its primary cause;

- Inadequate access to markets for the goods and services that the poor can sell: this is caused by their remote geographic location or other factors;

- Inadequate access to education, health, sanitation and water services. This emanates from inequitable Social service delivery which consequently results in the inability of the poor to live a healthy and active life and take full advantage of Employment opportunities;

- The destruction of the natural resources endowments, which has led to reduced productivity of agriculture, forestry and fisheries. This often resulted from the desperate survival strategies of the poor as well as inadequate and ineffective public policy on natural resource management;

- The inadequate access to assistance by those who are the victims of transitory poverty such as drought, floods, pests and war. This is brought about by lack of well-conceived strategies and resources.

\section{Theoretical Framework}

One of the first systematic attempts to link infrastructure indirectly to poverty reduction was made by Keynes (1936). From the General Theory of Employment Interest and Money, Keynes argues that in an economy characterized by depression and market failure, high public expenditure is necessary to adjust the economy back to high levels of employment. This implies that high public investment in infrastructure would increase national income, employment and the welfare of people.

This theory could be of practical importance in developing countries where the bulk of investment in infrastructure is owned and financed by government, and market mechanisms do not function properly. In the developing countries almost 70 per cent of infrastructure investments are financed by governments while the remaining per cent falls under local and international aids (NGOs), joint partnership (public-private partnership) and the smallest percentage comes from individual efforts (philanthropist).

In respect to this study, this theory focuses or suggests the need for high public investment on infrastructure in the rural areas. This is because the provision of public infrastructure in rural areas will enhance the welfare of the people and reduce the level of poverty in those areas.

\section{Methodology of Study}

The study adopted descriptive survey design in examining the relationship between public infrastructure and poverty reduction in Anyamelum local government areas. According to Ikeagwu(1997), Ezenwegbu, Shehu, \& Alfa, (2016), studies of this nature use the survey method to look for information on facts, attitudes, practice and opinions of the respondents.

Ayamelum is a Local Government Area in Anambra State, south-central of Anambra is with headquarter at Anaku. Towns that make up the local government are Omor, Umueje, Omasi, Igbakwu, Umumbo, Anaku, Umuerum, IfiteOgwari. The target population for this study was the indigenes or occupants ofAnyamelum. As at 2006 census, the population of the local government is 158,152 and 209,300 in the 2016 projection(National Population Commission of Anambra is (web), National Bureau of Statistics [web]).

The tools used for data collection from primary sources were questionnaires, interviews and personal observation and Questionnaire was analyzed using Statistical package for social science. The researchers made use of Taro Yemani's formula of 1964, for determining sample size from which is 204.

\subsection{Instrument of Study}

An item structured instrument was developed by the researcher. A modified five (5) point's Likert scale designed to reflect such options as: Strongly agree (SA) - 5 point, Agree (A) - 4 point, Undecided (UND) - 1 point, Disagree (D) - 3 point, Strongly disagree (SD) - 2 point, was used in collecting the data from the respondents. 


\section{Presentation of Data and Analysis}

\begin{tabular}{|c|c|c|c|c|c|c|c|c|}
\hline $\mathbf{S} / \mathbf{N}$ & Factors & (5) & (4) & (3) & (2) & (1) & $\begin{array}{l}\text { Mean } \\
\text { Score }\end{array}$ & Remark \\
\hline 1 & $\begin{array}{l}\text { Adequate provision of Public } \\
\text { infrastructures will play a role in } \\
\text { poverty reduction in Anyamelum } \\
\text { local government. }\end{array}$ & 55 & 55 & 34 & 25 & 34 & 3.38 & Agree \\
\hline 2 & $\begin{array}{c}\text { Public infrastructures will } \\
\text { improve economic development } \\
\text { and growth in Anyamelum local } \\
\text { government. }\end{array}$ & 106 & 56 & 16 & 25 & - & 4.27 & Agree \\
\hline 3 & $\begin{array}{l}\text { The bad condition of roads in } \\
\text { Anyamelum rural areas does } \\
\text { affect the agricultural and } \\
\text { commercial activities in areas. }\end{array}$ & 94 & 34 & 10 & 10 & 55 & 3.58 & Agree \\
\hline 4 & $\begin{array}{c}\text { Constructions and maintenance } \\
\text { of roads will enhance the } \\
\text { agricultural and commercial } \\
\text { activities in Anyamelum rural } \\
\text { areas. }\end{array}$ & 74 & 25 & 15 & 34 & 55 & 2.72 & Agree \\
\hline 5 & $\begin{array}{l}\text { Absence of skill acquisition and } \\
\text { vocational centers undermined } \\
\text { the potentials of youths in } \\
\text { Anyamelum local government } \\
\text { area. }\end{array}$ & 24 & 14 & 35 & 25 & 105 & 2.05 & Disagree \\
\hline 6 & $\begin{array}{l}\text { There is high level of infant and } \\
\text { maternal mortality due to the } \\
\text { lack of healthcare center in } \\
\text { Anyamelum rural area. }\end{array}$ & 106 & 56 & 16 & 25 & - & 4.27 & Agree \\
\hline 7 & $\begin{array}{l}\text { Anyamelum local government } \\
\text { areas do not have access to } \\
\text { commercial banks and this } \\
\text { affects both the commercial and } \\
\text { economic activities in the area. }\end{array}$ & 105 & 56 & 16 & 26 & - & 4.27 & Agree \\
\hline 8 & $\begin{array}{l}\text { Inadequate power supply has } \\
\text { affected the growth and } \\
\text { development of small and } \\
\text { medium scale business or } \\
\text { Enterprise (SME) in Anyamelum } \\
\text { local government area. }\end{array}$ & 55 & 65 & 35 & 24 & 24 & 3.55 & Agree \\
\hline 9 & $\begin{array}{l}\text { The poor and inadequate market } \\
\text { facilities in Anyamelum local } \\
\text { government is also a bane to } \\
\text { economic and agricultural } \\
\text { development in the area. }\end{array}$ & 106 & 57 & 16 & 24 & - & 4.27 & Agree \\
\hline 10 & $\begin{array}{l}\text { Anyamelum economy is hostile } \\
\text { to investment and commercial } \\
\text { activities on many fronts such as } \\
\text { lacking steady and } \\
\text { sustainablepower supply, access } \\
\text { to medical facilities,pipe born } \\
\text { water, good road, security etc. }\end{array}$ & 109 & 8 & 23 & 54 & 9 & 1.69 & Agree \\
\hline
\end{tabular}

Table 1: Responses on the Ranking of the Statement onpublic Infrastructure and

Poverty Reduction in Anyamelum Local Government Source: Researchers Field Survey 2020

\subsection{Responses on Statement on Public Infrastructure and Poverty Reduction in Anyamelum Local Government}

The analysis on the Table above shows thatthe respondents agreed with all the statements of the items, except item five which the respondents disagreed that 'Absence of skill acquisition and vocational centers undermined the potentials of youths in Anyamelum local government area'. 


\section{Summary of the Major Findings}

The study revealed that, the level of poverty in Anyamelum local government rural area tend to be high because of the poor and inadequate public infrastructures in the area, such as roads, pipe borne water, well equipped hospital, market facilities and well equipped basic education, skill acquisition centers and so on.

The study also revealed that, the poor and inadequate power supply plus the poor road condition in the study area have discourage the growth and development of small and medium scale business or enterprise (SME) in the area. The condition of roads in the areas has reduced employment opportunity. Finally, the study revealed that, Anyamelum Local Government rural areas have only one bank which is a Micro-Finance Bank operating there. That is, there is no commercial bank operating in Anyamelum local Government and considering the population and size of agricultural activities in the area, one Micro-Finance bank is inadequate. This plus poor market facilities tend to be militating against agricultural and commercial activities in the areas.

\section{Conclusion}

The primary objective of this study was to check for infrastructural facilities on poverty reduction in the rural areas of Anambra State. Few or inadequate attempts have been observed through this study. Many areas have been observed to find out the results for this study like medical care, banking services, power supply, skill acquisition, employment opportunities, roads and literacy level etc. Lack of government initiatives also have been observed in this study. Proper public infrastructure scheme can make this area both socially and economically viable.

\section{Recommendations}

The government in Anambra have focused on the development of rural infrastructure. The infrastructural developments have been hampered by the faulty implementation. Poverty, disease and deaths, high unemployment and illiteracy have worsened the situation further. The study therefore made the following recommendations;

To eliminate poverty rate mainly in the rural areas compared to urbans,there is need for government to focus the provision or building of public infrastructures. Example; good road network, market structure, steady power supply, pipe borne water, Skill acquisition and vocational centers, well equipped Hospital and commercial banks. This is because the availability of these structures in rural areas will create employment opportunity, encourage the growth of small scale business or enterprise and finally will improve the agricultural activities in the area.

Anambra state Government should set up or establish a Modern Agency that will undertake the provision and maintenance of infrastructural facilities in rural areas. These programmes should be genuinely set and both the state and local government should be involved in the operationalization and implementation for improved standard of living of the rural people.

There is also need for government to improve the educational facilities (school structures, study materials and skill acquisition centers etc.) in the study area. This will enhance literacy and skill acquisition whereby reducing poverty in Anyamelum rural areas.

Finally, there is need for Anyamelum people to come together and form strong and modern community development associations and operative organizations so as to facilitate development of the area, basically in the area of infrastructure development. This will enhance the both agricultural and commercial activities in the area.

\section{References}

i. Aluko, 0. (2000). Gender and Poverty Alleviation in Nigeria. A Paper Presented at the 31st Annual I Conference of the Nigeria Institute of I Town Planners, (NITP).

ii. Ali, I., \& Pernia, E. m. (2003). Infrastructure and Poverty Reduction: What is the Connection? ERD policy brief series; economic and research department.13. Manila: Asia Development Bank. Retrieved from http:www.adb.org/economics/default.asp

iii. Ezenwegbu, N. C., Shehu, A. A., \& Alfa, M. (2016). Effect of Unemployment on Internal Security in Nigeria (A Study of Onitsha in Anambra State). Nigeria Journal of Applied Arts and Sciences, Federal Polytechnic, Bida, 9(1), 92-105.

iv. OECD. (2007). Scaling Up and Improving Infrastructure for Poverty Reduction, in Promoting Pro-Poor Growth: Policy Guidance for Donors,. Paris: OECD Publishing. doi:https://doi.org/10.1787/9789264024786-21-en

v. Shehu, A. A., Ezenwegbu, N. C., \& Suleiman, S. (2015). public infrastructure and poverty reduction in Edati local governmentof Niger State. Jounal of School of Environmental Studies Federal Polytechnic, Bida, 8(2), 36.

vi. Bradshaw, T. (2006). Theories of Poverty and Anti-Poverty Programmes in Community Development. Rural Poverty Research Centre (RPRC) Working Paper No. 06-05.

vii. Central Bank of Nigeria, Research Department (1999) Nigeria's Development Prospects: Poverty Assessment and Alleviation Study|: (Abuja: CBN).

viii. Federal Office of Statistics (FOS, now National Bureau of Statistics) (1996), Socio-Economic Profile of Nigeria, yearly publication, FOS office Abuja, Nigeria,

ix. World Bank (2003). World Development Report 2000/2001: Attacking Poverty. New York: Oxford University Press. 